\title{
Methodology of Determining Scope of Executability of Right of Transmission Easement for Overhead Power Lines
}

\begin{abstract}
Transmission easement as the basic legal title obtained by entrepreneurs permits the construction and later exploitation of transmission devices in the space of another person's land property. It also allows for the regulation of unfavorable circumstances; i.e., situations where the devices were constructed without a held legal title to the land.

The execution of transmission easement should be implemented in the necessary scope. The methodical and precise determination of its range, therefore, is important, because it also translates into a limitation of the constitutionally-protected ownership right. The scope of executability of the said right (the so-called "area of transmission easement") in turn affects the amount of compensation payable to the owner of the encumbered land property, defined as compensation for any damage related to the construction and existence of transmission devices in the space of another person's land property and remuneration for the establishment of the right itself.

The objective of the article is to develop a methodology of determining the scope of executability of the right of a transmission easement based on the example of overhead power lines.

Keywords: transmission easement, transmission devices, power lines
\end{abstract}

\footnotetext{
* Warsaw University of Technology, Faculty of Geodesy and Cartography, Department of Cadastre and Land Management, Warsaw, Poland
} 


\section{Introduction}

Transmission devices have a negative effect on the spatial conditions of a land property, decreasing its environmental and landscape values, limiting the possibility of efficient land management, and (as a consequence) decreasing its value. The scale of such "inconveniences" particularly depends on the type of infrastructure (including its technical parameters), location as related to the land surface, course of running through the land property, and (as our analysis will show) purpose of the land property.

Starting on May 3, 2008, when a new limited property right of transmission easement [15] was introduced to the Polish legislature, discussions have been conducted among the owners of land properties and transmission companies as well as in the environment of property valuers, surveyors, and lawyers, regarding the properties of determination of the scope of executability of transmission easement. A lack of legal regulations authoritatively determining the range of the said right as well as a lack of uniform and coherent rules of its determination at the national scale result in a lack of trust in terms of justifying the scopes defined by transmission companies (Tab. 1).

Table 1. Scopes of execution of transmission easement by transmission companies depending on voltage of electrical transmission lines

\begin{tabular}{|c|c|c|c|c|c|c|c|c|c|}
\hline \multirow{3}{*}{ No. } & \multirow{3}{*}{$\begin{array}{c}\text { Voltage } \\
{[\mathrm{kV}]}\end{array}$} & \multicolumn{8}{|c|}{ Transmission company } \\
\hline & & A & B & $\mathrm{C}$ & $\mathrm{D}$ & E & $\mathrm{F}$ & G & $\mathrm{H}$ \\
\hline & & \multicolumn{8}{|c|}{$\begin{array}{l}\text { Scope of execution of right of transmission easement [m] } \\
\text { (so-called transmission easement belt with axis of device in its center) }\end{array}$} \\
\hline 1 & 110 & 2.5 & 6.0 & 1.6 & - & - & - & - & - \\
\hline 2 & 30 & - & 6.0 & - & - & - & - & - & 0.5 \\
\hline 3 & 20 & 1.0 & 3.0 & - & - & - & - & - & - \\
\hline 4 & 15 & 1.0 & 3.0 & $1.1-2.0$ & 1.0 & 0.6 & - & - & - \\
\hline 5 & 6 & 1.0 & 3.0 & - & - & - & 6.0 & 1.0 & 0.5 \\
\hline 6 & $<1$ & 0.7 & 1.0 & $1.0-1.3$ & 0.6 & - & 3.0 & - & - \\
\hline
\end{tabular}

Source: own elaboration based on survey conducted among transmission companies

Results of the survey presented in Table 1 show even 12 -fold differences (marked in red) in the scopes of execution of the right of transmission easement by particular transmission companies in the space of another person's land property. The scopes should be defined as the so-called "widths of transmission easement belts," the middle of which is determined by the axis of the transmission device. 


\section{Objective and Scope of This Paper}

The objective of the paper is the development of a methodology of determination of the scope of executability of the right of transmission easement within the boundaries of encumbered land properties.

The methodology will be developed for overhead electrical transmission lines as the most-common transmission devices simultaneously requiring the regulation of unfavorable circumstances to the highest degree [17].

\section{Materials and Methods}

The data used for the study was based on:

- cadastral data bases obtained from governmental institutions dealing with the storage of cadastral data;

- electronic land and mortgage registers of land properties [18], particularly including the provisions of Chapter III providing information on established transmission easements (among others);

- architectonic-construction documentation obtained from the Warmia and Mazury Voivodeship Office in Olsztyn;

- legal documentation available on websites of governmental and self-governmental organizations.

The study particularly applies observation methods, scientific surveys, and comparative analyses aimed at:

- investigating and assessing the rules of determination of transmission easement by transmission companies;

- analyze legal acts, technical norms, and industry guidelines for the purpose of searching for provisions referring to the issue of determining the right of transmission easement.

\section{Research Area}

The analysis of the scope of executability of the right of transmission easement was performed based on the example of the investment of the double-track electrical transmission line $400 \mathrm{kV}$ between Ełk and the border of Poland, the so-called "power connection between Poland and Lithuania" (Fig. 1).

The investment constituted a public-purpose implementation as defined in the act on real estate management [13], and was 1 of 23 strategic investments in the scope of transmission networks [16].

The course of the double-track electrical transmission line $400 \mathrm{kV}$ Ełk-border of Poland runs through two voivodeships, four poviats, and ten communes. The trans- 
mission company of the said overhead electrical transmission line is Polskie Sieci Elektroenergetyczne S.A. (PSE).

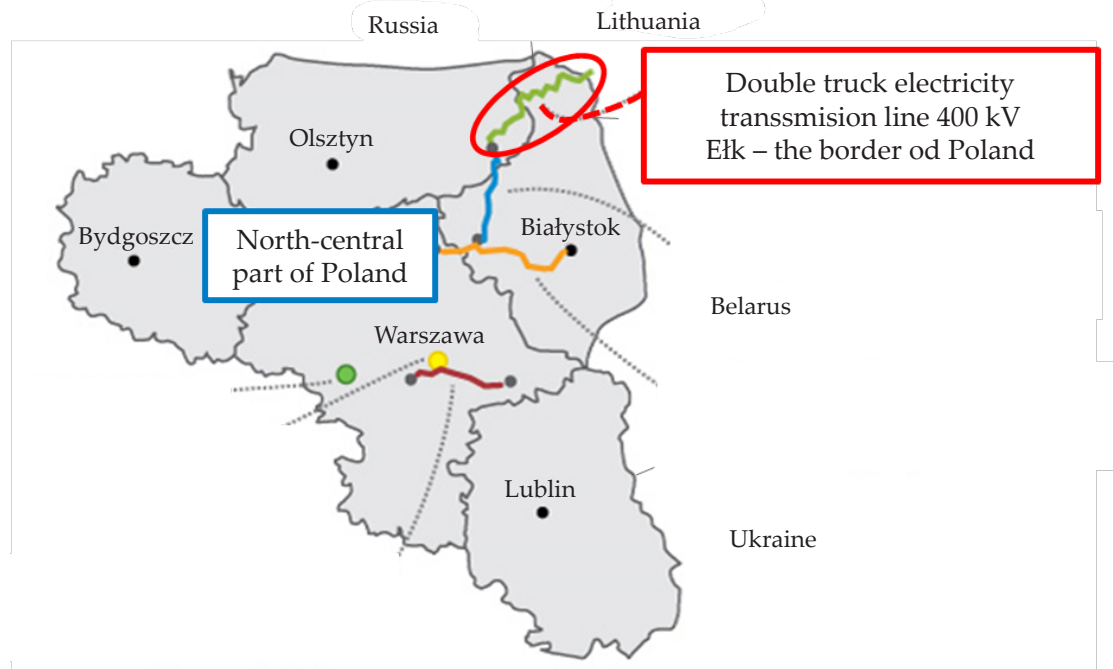

Fig. 1. Location of double-track electrical transmission line $400 \mathrm{kV}$ Ełk-border of Poland (on background of Poland and Europe)

Source: own study based on [19]

For the purposes of the implementation of the investment along the course of the line, decisions on the determining the location of the public purpose investment were issued or local spatial development plants were passed, establishing so-called "technological belts" with a width of $70 \mathrm{~m}$; i.e., $35 \mathrm{~m}$ on both sides of the axis of line $400 \mathrm{kV}$ (Fig. 2). Within the belts, a ban was established on the construction and exploitation of buildings for permanent residency and maintenance of high vegetation, among others.

For the purpose of obtaining a legal title providing the right to administer land property for construction purposes and a guarantee of later exploitation of the device, PSE requested the establishment of transmission easement ${ }^{21}$ within the so-called "technological belt."

The analysis of the provisions of Chapter III of the land and mortgage registers of the land property through which the said electrical transmission line runs showed that the transmission easement was established both on land properties constituting the property of private persons and those belonging to the State Treasury and remaining under the administration of the State Forest Enterprise.

1 In the case of a lack of consent of the owners of the land property to establish transmission easement, the legal title to administer the land property for construction purposes was obtained pursuant to the provisions of Art. 124, Par. 1 of the Act on Real Estate Management [13]. 


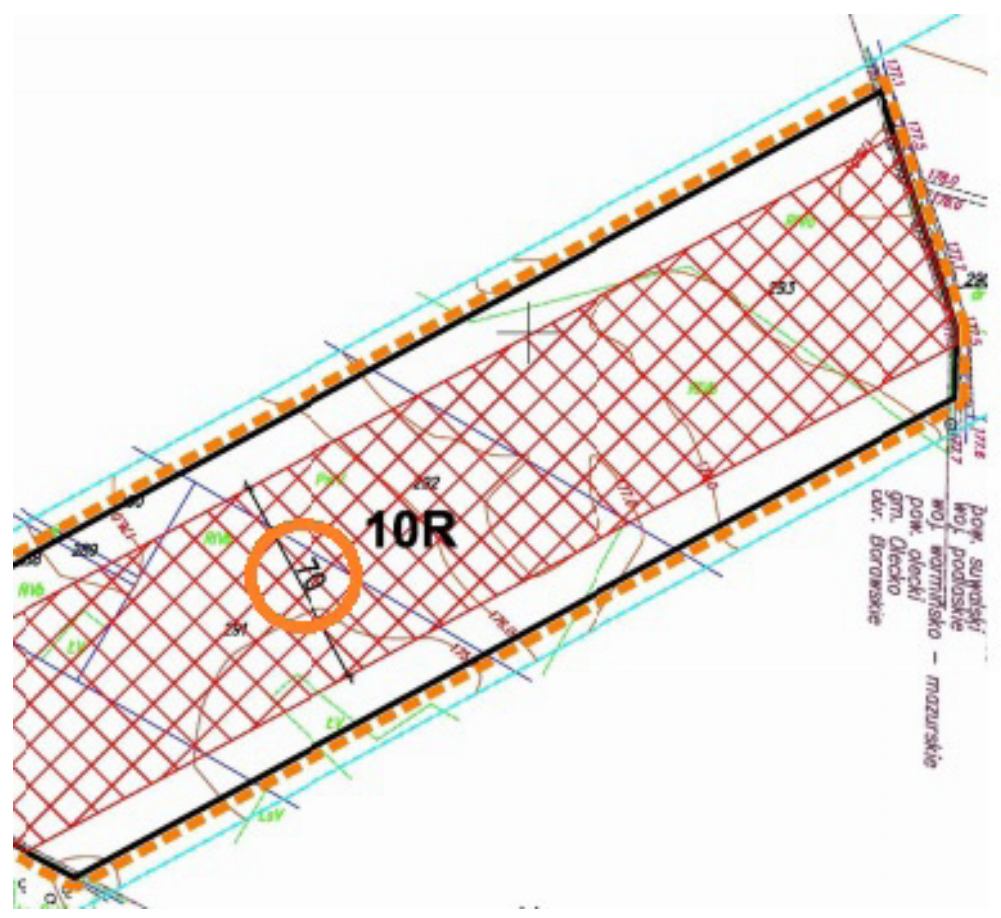

Fig. 2. Example graphic part of local spatial development plan.

Source: own study based on [3]

All of the established transmission easements were subject to payment and were indefinite in time. The scope of their content was different, but it usually included the following:

a) the right to use the land property for the purposes of construction and later functioning of the said line with any objects and devices necessary for its exploitation through suspending overhead conductors of the line and the potential construction of pillars;

b) right to use the devices in accordance with their purpose, including the right to access, entrance, crossing on foot, and by necessary vehicles by persons entitled by the investor to perform activities related to the construction, exploitation, maintenance, renovation, modernization, reconstruction, and elimination of failures of the line;

c) obligation to bear with the presence of the said devices on the land property;

d) obligation to bear with limitations and bans resulting from the existence of the technological belt of the line with a width of $70 \mathrm{~m}$;

e) right to use the land property through clearing the existing trees and bushes in the scope necessary for construction of the line; i.e., specified in a decision on the exclusion of land from forest production. 
The arbitrarily determined scope of the executability of the right of transmission easement along the entire line was justified by PSE with the necessity of maintaining the threshold values of the components of the electromagnetic field and level of noise.

\section{Research Methodology}

The common character and scale of the limitations resulting in the establishment of a transmission easement require the verification of the transmission solutions currently applied by transmission companies. The analysis of legal provisions, norms, and technical guidelines as well as the core of the issue permit the development of a methodology of determination of the scope of executability of this limited property right.

Currently, designing and constructing overhead electrical transmission lines is subject to relevant norms:

- for overhead lines of alternating current of greater than $1 \mathrm{kV} \mathrm{[6];}$

- for overhead lines of low voltage with bare conductors [4];

- for overhead lines with fully isolated conductors and with partially isolated conductors [2].

In reference to electrical transmission lines, analogically as in the case of the remaining transmission devices, no provision exists that should directly define the scopes of executability of the right of transmission easement. The provision resulting from Art. 144 of the Environmental Protection Law Act is important for the discussed issue [14]. It stipulates that, outside the territory to which the party introducing the installation has a legal title (e.g., transmission easement), the standards of environmental quality cannot be exceeded. Therefore, in reference to overhead electrical transmission lines, it stipulates maintenance of the threshold levels of noise emission and electromagnetic fields.

The act also introduces a provision stating that, if an area of limited use is established in relationship to the functioning of the installation, the exploitation of the installation should not cause the environmental quality standards to exceed outside the area. The establishment of the aforementioned area entails the consequences of the potential payment of compensation or repurchase of the land property if its current use or use in accordance with its purpose is impossible. The payer of compensation is the party whose activity caused the introduction of limitations.

Due to the above, both for the purposes of determining the scope of executability of the right of transmission easement and establishment of the area of limited use for overhead electrical transmission lines, boundaries should be established within which the acceptable levels of electromagnetic fields [7] and levels of noise [8] will be exceeded.

Tables 2 and 3 present the physical parameters characterizing the effect of electromagnetic fields on the environment and their acceptable levels, respectively, for areas designated for residential building development and areas accessible to the public. 
Table 2. Acceptable levels of physical parameters characterizing electromagnetic field for frequencies of electrical network for areas designated for residential building development

\begin{tabular}{|c|c|c|}
\hline Range of frequencies of electromagnetic field & Electric component & Magnetic component \\
\hline \hline $50 \mathrm{~Hz}$ & $1 \mathrm{kV} / \mathrm{m}$ & $60 \mathrm{~A} / \mathrm{m}$ \\
\hline
\end{tabular}

Source: own elaboration based on [7]

Table 3. Acceptable levels of physical parameters characterizing electromagnetic field for frequencies of electrical network for places accessible to public

\begin{tabular}{|c|c|c|}
\hline Range of frequencies of electromagnetic field & Electric component & Magnetic component \\
\hline \hline from $0.5 \mathrm{~Hz}$ to $50 \mathrm{~Hz}$ & $10 \mathrm{kV} / \mathrm{m}$ & $60 \mathrm{~A} / \mathrm{m}$ \\
\hline
\end{tabular}

Source: own elaboration based on [7]

According to the above tables, the threshold value of the amperage of the magnetic component of the electromagnetic field for both areas accessible to people and those designated for residential building development equals $60 \mathrm{~A} / \mathrm{m}$ for frequencies of electrical networks (the highest voltages of 220-400 kV) amounting to $50 \mathrm{~Hz}$. Differences occur in the threshold levels of the electric component that should not exceed $1 \mathrm{kV} / \mathrm{m}$ for areas designated for residential building development nor $10 \mathrm{kV} / \mathrm{m}$ for places accessible to the public.

According to Szuba [12] in reference to overhead electrical transmission lines, the issue to resolve remains the threshold value of $1 \mathrm{kV} / \mathrm{m}$, because all lines are designed in such a way to avoid exceeding $10 \mathrm{kV} / \mathrm{m}$ for an electric component (Fig. 3) and $60 \mathrm{~A} / \mathrm{m}$ for a magnetic component (Fig. 4) in any place accessible to the public in Poland.

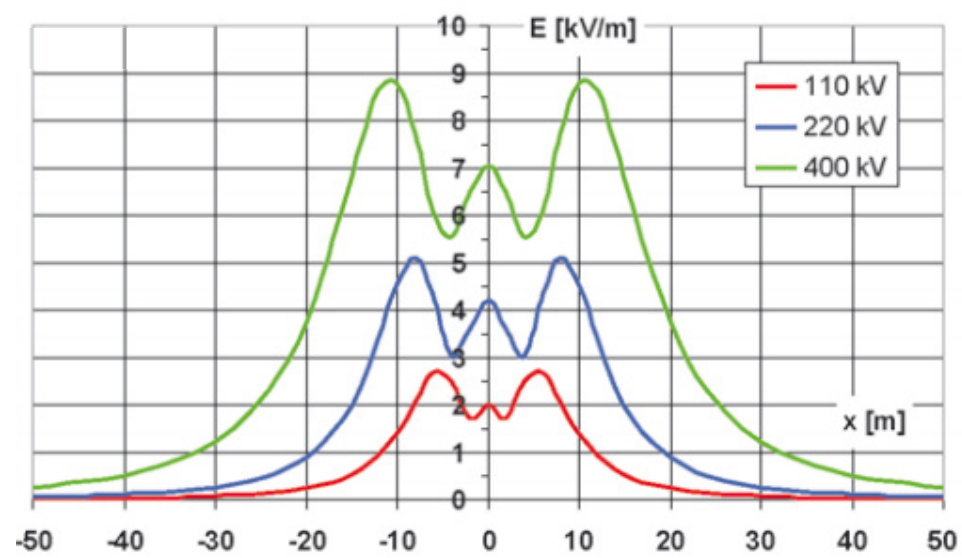

Fig. 3. Example distributions of electric field in surroundings of high-voltage electrical transmission lines

Source: [9] 


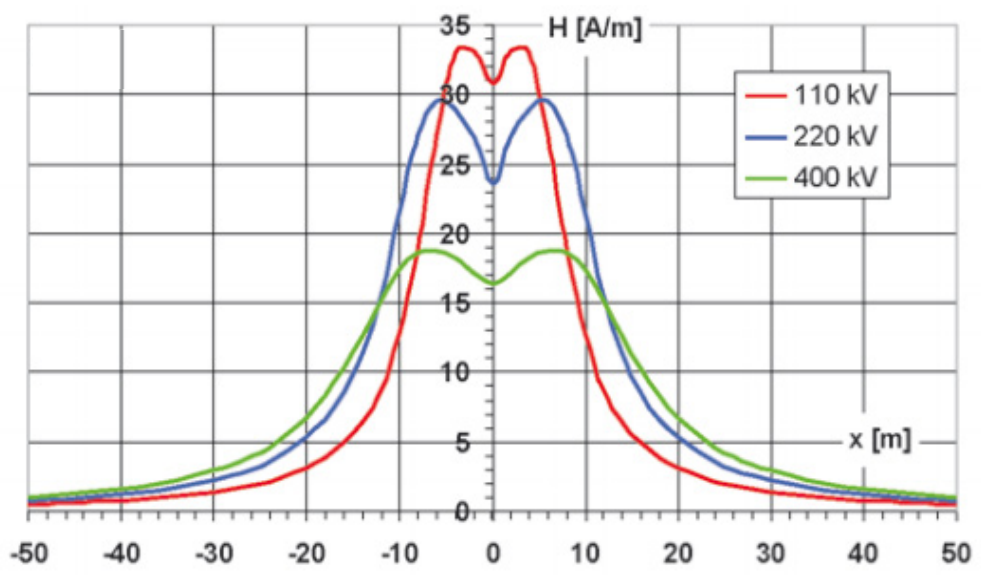

Fig. 4. Example distributions of magnetic field in surroundings of high-voltage electrical transmission lines

Source: [9]

According to regulation [8], the acceptable level of noise is only subject to the norm for built-up areas. Legal provisions do not regulate the threshold values of noise levels for agricultural and forested areas.

The acceptable values of indicators LDWN (day-evening-night level) and LN (longterm level) that are applicable for conducting a long-term policy in the scope of protecting against noise from overhead electrical transmission lines are presented in Table 4 .

Table 4. Acceptable levels of long-term medium level of noise expressed in LDWN and LN indicators.

\begin{tabular}{|c|c|c|c|}
\hline \multirow[b]{2}{*}{ No. } & \multirow[b]{2}{*}{ Type of land } & \multicolumn{2}{|c|}{$\begin{array}{l}\text { Acceptable long-term medium level } \\
\text { of noise } A[\mathrm{~dB}]\end{array}$} \\
\hline & & $\begin{array}{l}\text { LDWN reference } \\
\text { period equal to } \\
\text { all days in a year }\end{array}$ & $\begin{array}{l}\text { LN reference } \\
\text { period equal to } \\
\text { all times at night }\end{array}$ \\
\hline 1. & $\begin{array}{l}\text { Protection zone " } \mathrm{A} \text { " health resorts; premises of } \\
\text { hospitals, public nursing homes; areas of building } \\
\text { development related to permanent or temporary stay of } \\
\text { children and youth }\end{array}$ & 45 & 40 \\
\hline 2. & $\begin{array}{l}\text { Areas of single- and multi-family homestead and } \\
\text { collective residency development; recreational areas; } \\
\text { residential and service areas; areas in centers of cities } \\
\text { with a population of more than } 100 \text { thousand }\end{array}$ & 50 & 45 \\
\hline
\end{tabular}

Source: own elaboration based on [8]

In forested areas, potential expansion of the range of transmission easement needs to be additionally considered due to the clearing of trees. Pursuant to the norm [4], distance ( $a$ ) of a non-earthed conductor of an overhead electrical transmis- 
sion line of up to $45 \mathrm{kV}$ to each point of a tree crown in windless weather and normal overhang should amount to at least:

$-1.0 \mathrm{~m}$ in the case of a line with a voltage of up to $1 \mathrm{kV}$;

- in the case of a line with a voltage greater than $1 \mathrm{kV}$ :

$$
a=2.5+\frac{U}{150}+s[\mathrm{~m}]
$$

where:

$U$ - rated voltage of the electrical transmission line $[\mathrm{kV}]$,

$s$ - value of five-year-growth increment specific to the species and habitat of the tree $[\mathrm{m}]$.

Therefore, the width of clearing belt $\left(S_{w}\right)$ should amount to the following:

- for lines with a voltage of up to $1 \mathrm{kV}$ :

$$
S_{w}=B+2[\mathrm{~m}]
$$

- for lines with a voltage greater than $1 \mathrm{kV}$ :

$$
S_{w}=B+2 \cdot\left(2.5+\frac{U}{150}+s\right)[\mathrm{m}]
$$

where $B$ - width of the electrical transmission line (distance between the outermost working conductors $[\mathrm{m}])$.

Moreover, in the case of a reduced distance between conductors and fruit or decorative trees, distances calculated from the above formulas should be increased by at least $1 \mathrm{~m}$ (for gardening tools).

Due to the above, the width of clearing belt $\left(S_{w}\right)$ for orchards should amount to the following:

- for lines with a voltage of up to $1 \mathrm{kV}$ :

$$
S_{w}=B+4[\mathrm{~m}]
$$

- for lines with a voltage greater than $1 \mathrm{kV}$ :

$$
S_{w}=B+2 \cdot\left(2.5+\frac{U}{150}+s\right)+2[\mathrm{~m}]
$$

In reference to isolated working conductors, pursuant to the norm [2], distances (a) of conductors from tree trunks and branches should amount to at least [1]:

- $0.5 \mathrm{~m}$ from conductors with full isolation,

- $1.0 \mathrm{~m}$ from conductors with partial isolation. 
Due to the above, the width of clearing belt $\left(S_{w}\right)$ will amount to the following, respectively:

- for fully isolated conductors:

$$
S_{w}=B+1[\mathrm{~m}]
$$

- for partially isolated conductors:

$$
S_{w}=B+2[\mathrm{~m}]
$$

Pursuant to the norm [5], the width of the tree-clearing belt for lines with a voltage of greater than $45 \mathrm{kV}$ should amount to:

$$
S_{w}=B+2 \cdot\left(2.5+\frac{U}{150}\right)[\mathrm{m}]
$$

The width of the clearing belt should also consider the growth increment of trees and periodic cleaning of the clearing area in accordance with the design specification.

Moreover, if resulting from the design specification, additional clearing should concern those trees located along the line that could damage the line in case of tipping. The height of such trees is specified based on the following formula:

$$
H_{d}>\sqrt{l^{2}+\Delta h}-\frac{U}{150}[\mathrm{~m}]
$$

where:

$H_{d}$ - height of the tree with consideration of the average increment of height over a five-year period $[\mathrm{m}]$,

l- horizontal distance of the tree trunk at the ground to the outermost conductor of the electrical transmission line [m],

$\Delta h$ - difference of levels of the conductor with a temperature of $+10^{\circ} \mathrm{C}$ and ground level at the tree trunk, in a plane perpendicular to the direction of the line $[\mathrm{m}]$.

Clearing trees with a height of $H_{d}$ is not required when the trees grow in isolation, in an open space, and (due to this) show a higher resistance to breaking and tipping.

In the case of constructing electrical transmission lines over forests for which the height of the suspension of conductors considers the maximum height of trees throughout the growth period, the clearing of trees is performed only for the purposes of the construction of pillars over the forest. 


\section{Results and Discussion}

For the purpose of determining the scope of executability of the right of transmission easement for overhead electrical transmission lines (Fig. 5), it should first be determined whether an area of limited use was established. If yes, this means that the threshold levels of electromagnetic fields and noise are exceeded in the area. In such a case, the range of transmission easement should correspond with the horizontal projection of the outermost conductors or other elements of the structure of the pillar on the $(x, y)$ plane, potentially increased by a width ensuring the movement of necessary equipment for performing exploitation activities. In forested areas, the range should additionally include an area that covers the necessary tree clearing.

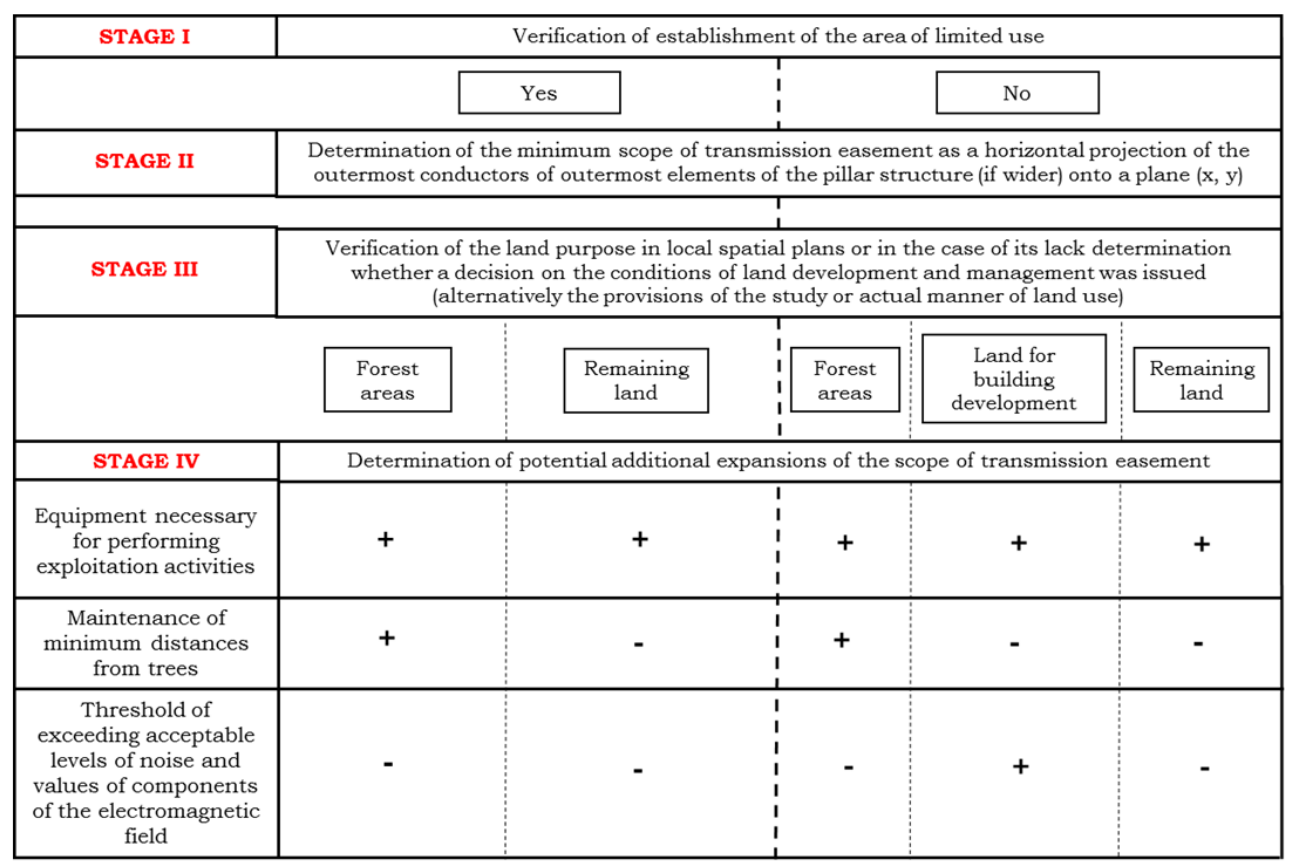

Fig. 5. Methodology of determining scope of executability of right of transmission easement for overhead electrical transmission lines

Source: own elaboration based on [11]

For overhead electrical transmission lines for which no area of limited use was established, the scope of execution of the right of transmission easement (apart from the rules presented above) should be expanded to boundaries in which the acceptable levels of noise and values of the components of the electromagnetic fields are exceeded in reference to the land designated for building development (in accordance with the systematics stipulated in Regulations [7, 8]). Such expansions will 
not be applicable in agricultural and forested areas, because Regulation [8] does not provide norms for acceptable levels of noise for land designation other than for building development, and the electric and magnetic components for lines designed in Poland do not exceed values of $10 \mathrm{kV} / \mathrm{m}$ (for areas accessible to the public) nor $60 \mathrm{~A} / \mathrm{m}$, respectively, in any place.

The methodology of determination of the scope of executability of the right of transmission easement for overhead electrical transmission lines is illustrated in Figure 5.

\section{Summary and Conclusions}

The range of transmission easement should always constitute its justified scope necessary for the functioning of the device. According to the study, the basis of its determination (in addition to the type and technical parameters of the transmission device) should be particularly land purpose. Moreover, while defining the scope of the transmission easement, the manner of conducting the exploitation economy (crossing with a vehicle or specialized equipment) should be considered. The resulting determined area corresponds with the active character of transmission easement (Fig. 6).

Moreover, in reference to areas designated for building development, the boundary of execution of the said right should also consider the threshold values of the levels of electromagnetic fields and noise emission. In the case when the range resulting from exceeding environmental quality standards and necessity of withholding planting trees exceeds the active transmission easement, its passive character occurs (Fig. 6).

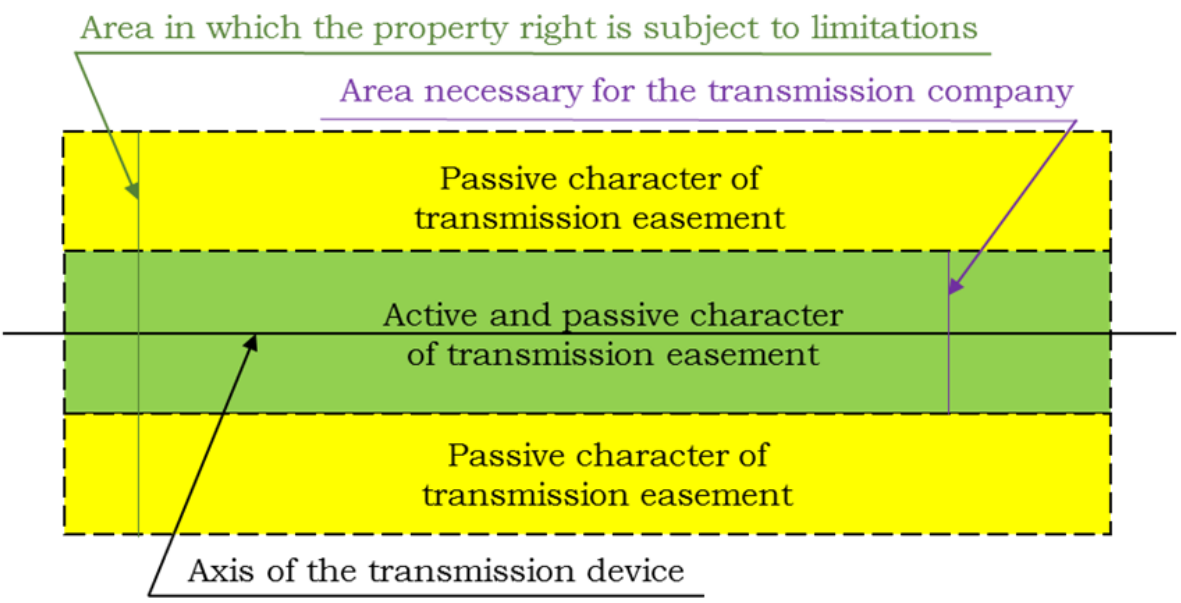

Fig. 6. Active and passive character of transmission easement. 
The determined range of a transmission easement should not be affected by the surface area necessary for eliminating failures. Both the place of their origin and the accompanying activities are incidental, and in the case of a lack of consent of owners of land properties to the performance of relevant activities, transmission companies can use the provisions of Art. 124b of the Act on Real Estate Management [13] pursuant to which the starost obligates the owner to make the land property available for the purpose of the performance of activities related to the elimination of the failure. For any related damage, the owner of the land property is entitled to compensation.

\section{References}

[1] Gładykowski F.: Zagrożenie dla linii napowietrznej $15 \mathrm{kV}$ ze strony drzew rosnacych w pobliżu [Threat to overhead line $15 \mathrm{kV}$ from trees growing in the vicinity]. Inżynier Budownictwa, R. 15, nr 2, 2012, pp. 19-21.

[2] N-SEP-E-003, Elektroenergetyczne linie napowietrzne. Projektowanie i budowa. Linie pradu przemiennego z przewodami petnoizolowanymi oraz z przewodami niepetnoizolowanymi [Overhead electricity transmission lines. Design and construction. Alternating current lines with fully isolated conductors and with partially isolated conductors]. COSiW, 2003.

[3] Plan 2013 uchwała nr ORN.0007.23.2013 Rady Gminy w Olecku Wieliczki z dnia 24 maja 2013 r. w sprawie miejscowego planu zagospodarowania przestrzennego dla dwutorowej, napowietrznej linii elektroenergetycznej 400 kV Ełk - granica RP na terenie gminy Olecko [Plan 2013 resolution No. ORN.0007.23.2013 of the Commune Council of Olecko of 24 May 2013 on the local spatial development plan for the double track overhead electricity transmission line $400 \mathrm{kV}$ Ełk-border of Poland in the territory of the Olecko Commune].

[4] PN-E-05100-1, Elektroenergetyczne linie napowietrzne. Projektowanie i budowa. Linie pradu przemiennego z przewodami roboczymi gołymi [Electricity transmission lines. Design and construction. Alternating current lines with bare working conductors]. Polski Komitet Normalizacyjny, Warszawa 1998.

[5] PN-EN 50341-3-22:2010, Elektroenergetyczne linie napowietrzne pradu przemiennego powyżej $45 \mathrm{kV}$. Część 3: Zbiór normatywnych warunków krajowych. Normatywne warunki krajowe dla Polski [Overhead electricity transmission lines of alternating current above $45 \mathrm{kV}$. Part 3: Collection of national normative conditions. National normative conditions for Poland]. Polski Komitet Normalizacyjny, Warszawa 2010.

[6] PN-EN 50341-1:2013-03, Elektroenergetyczne linie napowietrzne pradu przemiennego powyżej $1 \mathrm{kV}$ [Overhead electricity transmission lines of alternating current above 1kV]. Polski Komitet Normalizacyjny, Warszawa 2013. 
[7] Rozporzadzenie Ministra Środowiska z dnia 30 października 2003 r. w sprawie dopuszczalnych poziomów pól elektromagnetycznych w środowisku oraz sposobów sprawdzania dotrzymania tych poziomów. Dz.U. 2003, nr 192, poz. 1883 [Regulation of the Minister of the Environment of 30 October 2003 on accessible levels of electromagnetic fields in the environment and manners of verification of maintenance of such levels. Journal of Laws of 2003, No. 192, item 1883].

[8] Rozporzadzenie Ministra Środowiska z dnia 1 października 2012 r. zmieniajace rozporzadzenie w sprawie dopuszczalnych poziomów hałasu w środowisku. Dz.U. 2012, poz. 1109 [Regulation of the Ministry of Environment of 1 November 2012 changing the regulation concerning acceptable noise levels in the environment. Journal of Laws of 2012, item 1109].

[9] Różycki S.: Ochrona środowiska przyrodniczego przed polami elektromagnetycznymi. Informator dla administracji samorzadowej [Protection of the natural environment against electromagnetic fields. Information for self-governmental administration]. Generalna Dyrekcja Ochrony Środowiska, Warszawa 2011.

[10] Sajnóg N.: Infrastruktura techniczna zwiąana z przesyłem i dystrybucją mediów oraz towarzyszace jej pasy terenu [Technical infrastructure related to the transmission and distribution of media and the accompanying land belts]. Infrastruktura i Ekologia Terenów Wiejskich, nr 2014/II, 2014, pp. 467-480.

[11] Sajnóg N.: Metodyka określania zasięgu stużebności przesyłu dla potrzeb rejestracji w katastrze nieruchomości [Methodology of determination of transmission easement for the purposes of registration in the land cadastre]. Oficyna Wydawnicza Politechniki Warszawskiej, Warszawa 2016 [Ph.D. thesis].

[12] Szuba M.: Obszary ograniczonego użytkowania w otoczeniu elektroenergetycznych inwestycji liniowych [Areas of limited use in the surrounding of electricity transmission line investments]. [in:] Cymerman R. (red.), XVII Konferencja PFSRM „Inwestycje liniowe oraz ochrona środowiska jako szczególne obszary działania rzeczoznawcy majatkowego", Polska Federacja Stowarzyszeń Rzeczoznawców Majątkowych, Warszawa 2008, pp. 341-352.

[13] Ustawa z dnia 21 sierpnia 1997 r. o gospodarce nieruchomościami. Dz.U. 2016, poz. 2147 [Act of 21 August 1997 on real estate management. Journal of Laws of 2016, item 2147].

[14] Ustawa z dnia 27 kwietnia 2001 r. Prawo ochrony środowiska. Dz.U. 2017, poz. 519, 785, 898, 1089, 1529, 1566, 1888, 1999, 2056 [Act of 27 April 2001 Environmental protection act. Journal of Laws of 2016, item 519, 785, 898, 1089, 1529, 1566, 1888, 1999, 2056].

[15] Ustawa z dnia 30 maja 2008 r. o zmianie ustawy - Kodeks cywilny oraz niektórych innych ustaw. Dz.U. 2008, nr 116, poz. 731 [Act of 30 May 2008 on the amendment of the act - Civil Code and certain other acts. Journal of Laws of 2008, No. 116, item 731]. 
[16] Ustawa z dnia 24 lipca 2015 r. o przygotowaniu i realizacji strategicznych inwestycji w zakresie sieci przesyłowych. Dz.U. 2016, poz. 1812, z późn. zm. [Act of 24 July 2015 on the preparation and implementation of strategic investments in the scope of transmission networks. Journal of Laws of 2016, item 1812 with further amendments].

[17] Uzasadnienie do projektu ustawy o korytarzach przesyłowych $\mathrm{z}$ dnia 6 czerwca 2012 r. [Justification to the draft of the act on transmission corridors of 6 June 2012].

Websites:

[18] http://docplayer.pl/12132860-Folder-informacyjny-linia-elektroenergetyczna-elk-granica-rp-budujemy-w-harmonii-ze-srodowiskiem.html [access: 15.12.2017].

[19] https://ekw.ms.gov.pl/eukw_ogol/menu.do [access: 15.12.2017].

\section{Metodyka określania zakresu wykonywalności prawa służebności przesyłu dla napowietrznych linii elektroenergetycznych}

Streszczenie: Służebność przesyłu, jako podstawowy tytuł prawny pozyskiwany przez przedsiębiorców, umożliwia budowę oraz późniejszą eksploatację urządzeń przesyłowych w przestrzeni cudzej nieruchomości. Pozwala również na regulację tzw. zaszłości, czyli sytuacji, gdy urządzenia zostały wybudowane bez posiadanego tytułu prawnego do gruntu.

Wykonywanie służebności przesyłu powinno się odbywać w niezbędnym do tego zakresie. Metodyczne i precyzyjne wyznaczenie jej zasięgu jest więc niezwykle istotne, gdyż przekłada się na ograniczenie konstytucyjnie chronionego prawa własności. Zakres wykonywalności przedmiotowego prawa, tzw. powierzchnia służebności przesyłu, ma z kolei wpływ na wysokość rekompensat przysługujących właścicielowi nieruchomości obciążonej, rozumianych jako odszkodowania za szkody związane z budową i istnieniem urządzeń przesyłowych w przestrzeni cudzych nieruchomości oraz wynagrodzenia za ustanowienie samego prawa.

Celem artykułu jest opracowanie metodyki określania zakresu wykonywalności prawa służebności przesyłu na przykładzie napowietrznych linii elektroenergetycznych.

Słowa

kluczowe: służebność przesyłu, urządzenia przesyłowe, linie elektroenergetyczne 